76 巻 768 号 $(2010-8)$

\title{
マルチスケール解析による多孔質吸音材モデル*
}

\author{
山本崇史*1, 丸山新一*1, 泉井一浩*2 \\ 西脇 眞 二*2, 寺田 賢二郎*3
}

\section{A Model for Sound-Absorbing Poroelastic Material Using Multiscale Analysis}

\author{
Takashi YAMAMOTO*4, Shinichi MARUYAMA, Kazuhiro IZUI, \\ Shinji NISHIWAKI and Kenjiro TERADA \\ *4 Nissan Motor Co., Ltd. \\ 560-2 Okatsukoku, Atsugi-shi, Kanagawa, 243-0192 Japan
}

\begin{abstract}
In this paper we propose a model for sound-absorbing poroelastic materials using the homogenization method, based on the asymptotic approach. In contrast to the conventional Biot's model which is empirical and is not linked with the microstructure, the proposed model is consistent with microscopic structure and yields a macroscopic governing equation with properties predicted directly from microscopic geometry. In this model, four properties for the solid phase and two properties for the fluid phase are calculated by averaging characteristic functions of the periodic microscale model. These properties are then substituted into the macroscopic governing equations to evaluate performance such as the sound absorption coefficient for normal incidence. The proposed model is reduced to an equivalent monophasic model, i.e., an elastic solid model when the pore size is infinitely small, and a fluid model governed by the Helmholtz equation when the bulk modulus of the solid phase is sufficiently high compared to the bulk modulus of the fluid phase. Utilizing two-dimensional models with simple microscopic geometries where analytical solutions of sound absorption coefficients for normal incidence can be obtained, we show that the proposed method can provide accurate numerical solutions that converge to solutions obtained analytically as the discretization parameter of the microstructural model is made smaller. We also show how the actual size of the microscale affects the sound absorption coefficient, using a three-dimensional microstructure model.
\end{abstract}

Key Words: Sound and Acoustic, Simulation, Damping, Sound Absorption, Homogenization, Poroelastic Material

\section{1. 緒言}

自動車走行中の室内における静肃性の向上は，乗車 中の快適性を高める重要な要素である。その代表的な 方策の一つとして，フロアカーペットなどの多孔質吸 音材が多用されている．多孔質吸音材の性能を示す代 表的な特性は吸音率であり，その予測は多孔質吸音材 の設計に久かすことができない，一般的に多孔質吸音 材は，基材となる固体相と，数 $\mu \mathrm{m}$ 加数百 $\mu \mathrm{m}$ の径 の流路からなる流体相が混在した構造をしており，吸 音率などの特性はこの微視的な構造に大きく低存する.

* 原稿受付 2010 年 2 月 22 日。

*1 正員, 日産自動車 (株) (画 243-0192 厚木市岡津古久 560-2).

*2 正員, 京都大学大学院工学研究科機械理工学専攻 (汬606 8501 京都市左京区吉田本町).

*3 正員, 東北大学大学院工学研究科土木工学専攻 (矛 980-8579 仙台市青葉区荒巻字青葉 6-6-06).

E-mail : tks-yamamoto@mail.nissan.co.jp
吸音率を予測するために,これまで使われたきたモ

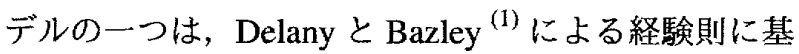
ブいたモデルである．必要となるパラメータは流れ 抵抗のみであるが，流体相しか考慮しておらず，さら に流体相の体積分率が大きい $100 \%$ に近い瀻維系の吸 音材に適用は限定される。 また, Biot ${ }^{(2)(3)}$, Allard ${ }^{(4)}$, Atalla ら ${ }^{(5)}$ による解析解に基づいたモデル (以降, Biot のモデルと呼ぶ) も近年広く適用されている。このモ デルは，固体相と流体相の両方の特性を考慮しており， 弾性定数や流れ抵抗など 8 つのパラメータで表現され ている. しかし，パラメータはマクロなスケールで定 義されており，多孔質吸音材の微視構造と直接関係付 けることはできない。

一方，多孔質体の微視構造からマクロスケールにお ける特性や支配方程式を導出することを目的とした研 究について，これまでにいくつか報告されている。こ 
れらの事例では土袞や岩盤などの多孔質体を対象とし たものが多く，いずれも均質化法を適用したものであ る. 例えば, Auliault ら ${ }^{(6)}$ は多孔質体の固体相が剛壁 で流体相の流れが定常である場合について Darcy 則 を導出し，実験による検証を行っている.Terada ら ${ }^{(7)}$ は多孔質体の固体相が弾性壁の場合について定式化 を行い，各相の挙動について数值計算を行っている. Levy ${ }^{(8)}$ や Burridge $5^{\left({ }^{(9)}\right.}$ は多孔質体の固体相が弾性 壁で，流体相が断熱的に振動する場合についてマクロ スケールにおける支配方程式を導出している。また， Boutin ら ${ }^{(10)}$ は多孔質体の流体相における熱散逸のみ を対象にし，均質化法を適用しマクロスケールにおけ る挙動を調べている。しかし，多孔質吸音材において は，固体相を構成する弾性体の挙動，流体相の媒質で ある空気の粘性流体としての挙動，および流体相で発 生する熱の挙動が相互に連成するマルチフィジクスの 問題となる。多孔質吸音材における物理現象からみる と，いずれの事例も現象の一部を报ったものになって いる.

そこで本論文では，流体相における粘性および熱の 散逸による隇衰，そして弾性体で構成される固体相と の連成の全ての現象を考慮し，ミクロスケールにおけ る支配方程式に漸近展開法に基づく均質化法を用いる ことで，マクロスケールにおける多孔質吸音材モデル を導出する，なお，筆者らは既報 ${ }^{(11)}$ において，多孔 質吸音材のミクロスケールにおけるモデルに均質化法 を適用し，等価密度などの均質化特性を求める手法を 提案しており，本論文においてもこの手法を取り込ん でいる。

2 章ではまず，本論文において提案するモデルとの 比較のため，まず Biotのモデルについて概説する。次 に 3 章で，本研究で適用するミクロスケールにおける 支配方程式を示し，4 章で漸近展開法に基づく均質化 法を適用しマクロスケールにおける平衡式および構成 式を導出する．また，そ机らを有限要素法により解く 場合に必要な弱形式を導き出す。最後に 5 章で，吸音 材の代表的なマクロ特性である垂直入射吸音率につい て本論文で提案する手法による数值解と理論解を比較 し有効性を検証する。

以下で用いる変位や圧力などの状態量は全て，角振 動数 $\omega$ で微小振幅の調和振動をするものと仮定し, 断 りのない限り周波数領域で表すものとする．また，流 体相の圧力, 温度, 質量密度に関しては平衡状態（压 力 $P_{0}$, 温度 $T_{0}$, 質量密度 $\left.\rho_{0}^{f}\right)$ からの変動量を表す. な お，固体相は線形弾性体，流体相は圧縮性の粘性流体 で構成され，流体相は全て連結しているものとする。

\section{Biot のモデル}

ここでは，本論文において提案するモデルとの比較 のため，まず Biot のモデルの平衡式と構成式を簡単 に説明する。詳細には文献 (2) (3) (4) (5) を参照されたい。 固体相および流体相の平衡式は，固体相の変位 $u_{i}^{s}$ と，流体相の圧力 $p^{f} に よ り p^{f}=-j \omega \psi^{f}$ と定義され るポテンシャル $\psi^{f}$ を用いて，それぞれ以下のように 表される。

$$
\begin{aligned}
\frac{\partial \hat{\sigma}_{i j}^{s}}{\partial x_{j}}+\tilde{\rho} \omega^{2} u_{i}^{s}-j \omega \tilde{\gamma} \frac{\partial \psi^{f}}{\partial x_{i}} & =0 \\
\frac{\phi^{2}}{\rho^{f c}} \frac{\partial^{2} \psi^{f}}{\partial x_{i}^{2}}+\omega^{2} \frac{\phi^{2}}{R} \psi^{f}-j \omega \tilde{\gamma} \frac{\partial u_{i}^{s}}{\partial x_{i}} & =0
\end{aligned}
$$

なお， $\tilde{\rho}=\rho^{s c}-\frac{\rho^{c c 2}}{\rho^{f c}}, \tilde{\gamma}=\phi\left(\frac{\rho^{c c}}{\rho^{f c}}-\frac{Q}{R}\right)$ である.ま た，固体相および流体相の構成式はそれぞれ次の式で 表される。

$$
\begin{aligned}
\sigma_{i j}^{s} & =\lambda^{s} \varepsilon_{k k}^{s} \delta_{i j}+2 \mu^{s} \varepsilon_{i j}^{s}-\frac{Q}{R} \phi p^{f} \delta_{i j} \\
\sigma^{f} & =-\phi p^{f}=Q \varepsilon_{k k}^{s}+R \varepsilon_{k k}^{f}
\end{aligned}
$$

以上の式において， $\sigma_{i j}^{s}, \sigma^{f}, \varepsilon_{i j}^{s}, \varepsilon_{i j}^{f}, \rho^{s}, \rho_{0}^{f}$ はそれ ぞれ固体相および流体相の応力，ひずみ，質量密度， $\lambda^{s}, \mu^{s}$ は固体相の Lamé の定数である。 $\hat{\sigma}_{i j}^{s}$ は流体 相との連成を考慮しない固体相のみの応力で $\hat{\sigma}_{i j}^{s}=$ $\lambda^{s} \varepsilon_{k k}^{s} \delta_{i j}+2 \mu^{s} \varepsilon_{i j}^{s}$ である。また, $\rho^{s c}, \rho^{c c}, \rho^{f c}$ は流体相 の粘性力を考慮した等価的な密度で, 空孔率 $\phi$, トー チユオシティ $\alpha_{\infty}$ ，空気流机抵抗 $\sigma$ ，粘性代表長さ $\Lambda$ というパラメータを用いて以下で表される.

$$
\begin{gathered}
\rho^{s c}=(1-\phi) \rho^{s}+\left(\alpha_{\infty}-1\right) \phi \rho_{0}^{f}+\frac{\sigma \phi^{2}}{j \omega} G(\omega) \\
\rho^{c c}=-\left(\alpha_{\infty}-1\right) \phi \rho_{0}^{f}-\frac{\sigma \phi^{2}}{j \omega} G(\omega) \\
\rho^{f c}=\phi \rho_{0}^{f}+\left(\alpha_{\infty}-1\right) \phi \rho_{0}^{f}+\frac{\sigma \phi^{2}}{j \omega} G(\omega) \\
G(\omega)=\left(1+\frac{4 j \omega \nu}{\Lambda^{2}} \frac{\rho^{f 2} \alpha_{\infty}^{2}}{\sigma^{2} \phi^{2}}\right)^{\frac{1}{2}}
\end{gathered}
$$

なお， $v$ は動粘性係数である. $Q, R$ は, 固体相の材 料そのものの体積弾性率 $K^{b}$ を用いて

$$
\begin{aligned}
& Q=\frac{\phi A_{1} K^{b}}{A_{1}+\phi A_{2}} \\
& R=\frac{\phi^{2} K^{b}}{A_{1}+\phi A_{2}}
\end{aligned}
$$

となる.ここで, $A_{1}=1-\phi-K^{s} / K^{b}, A_{2}=K^{b} / K^{f}$ で, $K^{s}$ は固体相の体積弾性率である. また， $K^{f}$ は熱散逸 を考慮した流体相の体積弹性率で, 温度代表長さ $\Lambda^{\prime}$ 
というパラメータを用いて次式で与えられる.

$$
K^{f}=\frac{\gamma P_{0}}{\gamma-(\gamma-1)\left[1+\frac{8 v^{\prime}}{j \omega \Lambda^{\prime 2}}\left(1+\frac{j \omega \Lambda^{\prime 2}}{16 v^{\prime}}\right)^{1 / 2}\right]^{-1}}
$$

ここで, $v^{\prime}$ は温度拡散率, $\gamma$ は比熱比である.

以上に示したように，固体相に関しては，Lamé の 定数 $\lambda^{s}, \mu^{s}$, 質量密度 $\rho^{s}$ の 3 つ, 流体相に関しては, 空孔率 $\phi$, トーチュオシティ $\alpha_{\infty}$, 空気流れ抵抗 $\sigma$, 粘 性代表長さ $\Lambda$, 温度代表長さ $\Lambda^{\prime}$ の 5 つのパラメータ が用いられている、これらはいずれもマクロなスケー ルで定義されており，多孔質吸音材の微視構造と直接 関保付けることはできない.

\section{3. 支 配 方 程 式}

多孔質吸音材のミクロスケールにおける支配方程式 について説明する．まず，固体相の支配方程式は弾性 テンソルを $c_{i j k l}^{s}$ として, 次に示す式で表される.

$$
\begin{aligned}
-\rho^{s} \omega^{2} u_{i}^{s} & =\frac{\partial \sigma_{i j}^{s}}{\partial x_{j}} \\
\sigma_{i j}^{s} & =c_{i j k l}^{s} \varepsilon_{k l}^{s} \\
\varepsilon_{k l}^{s} & =\frac{1}{2}\left(\frac{\partial u_{k}^{s}}{\partial x_{l}}+\frac{\partial u_{l}^{s}}{\partial x_{k}}\right)
\end{aligned}
$$

次に, 流体相に関しては, 速度を $v_{i}^{f}$, 質量密度を $\delta^{f}$ とすると流体相に関する質量保存則および状態方 程式は，それぞれ以下の式で表される.

$$
\begin{gathered}
\rho_{0}^{f} \frac{\partial v_{i}^{f}}{\partial x_{i}}+j \omega \delta^{f}=0 \\
\frac{p^{f}}{P_{0}}=\frac{\delta^{f}}{\rho_{0}^{f}}+\frac{\tau^{f}}{T_{0}}
\end{gathered}
$$

そして，流体相の流れ場に関する支配方程式は，以 下の線形化された Navier-Stokes の方程式で表される.

$$
\begin{aligned}
\rho_{0}^{f} j \omega v_{i}^{f} & =\frac{\partial \sigma_{i j}^{f}}{\partial x_{j}} \\
\sigma_{i j}^{f} & =-p^{f} \delta_{i j}+2 \mu^{f} \dot{\varepsilon}_{i j}^{f}-\frac{2}{3} \mu^{f} \delta_{i j} \dot{\varepsilon}_{k k}^{f} \\
\dot{\varepsilon}_{i j}^{f} & =\frac{1}{2}\left(\frac{\partial v_{i}^{f}}{\partial x_{j}}+\frac{\partial v_{j}^{f}}{\partial x_{i}}\right)
\end{aligned}
$$

ここで, $\mu^{f}$ は粘性你数である.

また，固体相の比熱は流体相の比熱に比して十分大 きく, 平衡状態での温度 $T_{0}$ を保持すると仮定すると, 流体相の温度場に関する支配方程式は, 熱力学の第一
法則より次式のように表すことができる.

$$
\begin{aligned}
-\frac{\partial q_{i}^{f}}{\partial x_{i}} & =j \omega \rho_{0}^{f} C_{v}^{f} \tau^{f}+\left(j \omega \rho_{0}^{f} R \tau^{f}-j \omega p^{f}\right) \\
q_{i}^{f} & =-\kappa_{i j}^{f} \frac{\partial \tau^{f}}{\partial x_{j}}
\end{aligned}
$$

ここで, $\tau^{f}, C_{v}^{f}, q_{i}^{f}, \kappa_{i j}^{f}$ はそれぞれ流体相の温度, 定 積比熱, 熱流速, 熱伝導率で, $R$ は気体定数である. なお, 式(20)の右辺第一項は単位体積あたりの内部工 ネルギー変化, 第二, 三項は状態方程式より外部仕事 を表している.

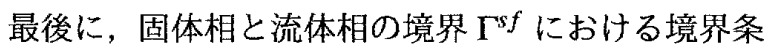
件は, 速度, 垂直応力および温度の連続性から, 次の ように書くことができる.

$$
\begin{aligned}
j \omega u_{i}^{s} & =v_{i}^{f} \\
\sigma_{i j}^{s} n_{j}^{s}+\sigma_{i j}^{f} n_{j}^{f} & =0 \\
\tau^{f} & =0
\end{aligned}
$$

ここで， $n_{i}^{s}, n_{i}^{f}$ はそれぞれ， $\Gamma^{s f}$ に立てた固体相，流 体相の領域外向きの単位法線ベクトルである.

\section{4. マルチスケール解析による多孔質体のモデル}

ここでは, 漸近展開に基づく均質化法の一般的な手 順 ${ }^{(12)}$ にしたがい, ミクロスケールのモデルからマク ロスケールにおける多孔質体モデルを導出する。すな わち, 状態量 $u_{i}^{s}, v_{i}^{f}, p^{f}, \tau^{f}, \delta^{f}$ に対してそれぞれ 漸近展開形の解

$$
\begin{aligned}
u_{i}^{s} & =u_{i}^{s(0)}(\boldsymbol{x}, \boldsymbol{y})+\varepsilon u_{i}^{s(1)}(\boldsymbol{x}, \boldsymbol{y})+\varepsilon^{2} u_{i}^{s(2)}(\boldsymbol{x}, \boldsymbol{y})+\cdots \\
v_{i}^{f} & =v_{i}^{f(0)}(\boldsymbol{x}, \boldsymbol{y})+\varepsilon v_{i}^{f(1)}(\boldsymbol{x}, \boldsymbol{y})+\varepsilon^{2} v_{i}^{f(2)}(\boldsymbol{x}, \boldsymbol{y})+\cdots \\
p^{f} & =p^{f(0)}(\boldsymbol{x}, \boldsymbol{y})+\varepsilon p^{f(1)}(\boldsymbol{x}, \boldsymbol{y})+\varepsilon^{2} p^{f(2)}(\boldsymbol{x}, \boldsymbol{y})+\cdots \\
\tau^{f} & =\tau^{f(0)}(\boldsymbol{x}, \boldsymbol{y})+\varepsilon \tau^{f(1)}(\boldsymbol{x}, \boldsymbol{y})+\varepsilon^{2} \tau^{f(2)}(\boldsymbol{x}, \boldsymbol{y})+\cdots \\
\delta^{f} & =\delta^{f(0)}(\boldsymbol{x}, \boldsymbol{y})+\varepsilon \delta^{f(1)}(\boldsymbol{x}, \boldsymbol{y})+\varepsilon^{2} \delta^{f(2)}(\boldsymbol{x}, \boldsymbol{y})+\cdots
\end{aligned}
$$

を仮定し，ミクロスケールにおける一連の支配方程式 (12)〜(24) に代入する. そして，عのオーダーごとに ついて関係式を立て，そこからマクロスケールにおけ る支配方程式を導出する．なお， $x$ はマクロスケール における空間変数, $\boldsymbol{y}$ はミクロスケールにおける空間 変数で $\boldsymbol{y}=\boldsymbol{x} / \varepsilon(\varepsilon \ll 1)$ である. また, 上式右辺の全 ての項はyについて周期的（ $Y$-periodic）である.

$4 \cdot 1$ スケーリング ミクロスケール，マクロス ケールの代表長さをそれぞれ $l, L$ とし，その比を $\varepsilon=l / L$ とする. また，微視構造は周期的であると仮 定し，その単位領域（ユニットセル）を $Y$ とする。こ こでは，l はユニットセルの大きさ，Lは多孔質体に おける波長の長さにとる. 一般的な吸音材料では, 空 
孔の大きさは数 $\mu \mathrm{m}$ から数百 $\mu \mathrm{m}$ であり，ユニット セルの大きさはその数倍程度でほぼ同じオーダーと考 えられる。 また，対象周波数の上限を $6.4 \mathrm{kHz}$ とする と，その上限周波数において音の波長は空気中で約 50 $\mathrm{mm}$, 吸音材料内部では一般にそれより波長は若干短 くなるもののオーダーは同じである ${ }^{(13)}$.したがって, $\varepsilon$ としては $1.0 \times 10^{-2}$ あるいはそれ以下のオーダーと なり，スケール分離ができることが分かる。

多孔質体による吸音は主として流体相において，固 体相との境界付近で生じる粘性減衰と熱散逸に起因す る.これらの効果が卓越する領域の大きさをそれぞれ 粘性境界層厚さ $\delta_{v}$, 温度境界層憬さ $\delta_{t}$ といい, 以下 のように表される。

$$
\delta_{\nu}=\left(\frac{\mu^{f}}{\rho_{0}^{f} \omega}\right)^{1 / 2}, \delta_{t}=\left(\frac{\kappa_{0}^{f}}{\rho_{0}^{f} \omega C_{p}^{f}}\right)^{1 / 2}
$$

ここで， $\kappa_{0}^{f}$ は流体の媒質の特性としての熱伝尊率， $C_{p}^{f}$ は定圧比熱を表す。これらの大きさは，多孔質体に吸 音効果がある場合, 多孔質体の空孔の大きさのスケー ルにほぼ等しい，このことを考慮すると，式(25)から 以下の関係式を得ることができる。

$$
O\left(\frac{\mu^{f} / L^{2}}{\rho_{0}^{f} \omega}\right)=O\left(\frac{\kappa_{0}^{f} / L^{2}}{\rho_{0}^{f} \omega C_{p}^{f}}\right)=O\left(\varepsilon^{2}\right)
$$

これより，式 (18)と (21) はそれぞれ次のように書き 直すことができる。

$$
\begin{aligned}
\sigma_{i j}^{f} & =-p^{f} \delta_{i j}+2 \varepsilon^{2} \mu^{f} \dot{\varepsilon}_{i j}^{f}-\frac{2}{3} \varepsilon^{2} \mu^{f} \delta_{i j} \dot{\varepsilon}_{k k}^{f} \\
q_{i}^{f} & =-\varepsilon^{2} \kappa_{i j}^{f} \frac{\partial \tau^{f}}{\partial x_{j}}
\end{aligned}
$$

これは，粘性による減衰や熱の拡散はミクロレベルで 生じるためマクロな視点では見えないことを意味して いる.

4.2 各オーダーごとの関係式 まず, 式(12)の $\varepsilon^{-2}$ のオーダーから

$$
\frac{\partial \sigma_{i j}^{s(-1)}}{\partial y_{j}}=0
$$

を得ることができる．また，(17)の $\varepsilon^{-1}$ のオーダー 加

$$
\frac{\partial \sigma_{i j}^{f(0)}}{\partial y_{j}}=0
$$

が成り立つ、式(12)，(17)，(20)，(13)，(18)，(15)，(16) の $\varepsilon^{0}$ のオーダーからは以下に示す式を得ることがで
きる。

$$
\begin{aligned}
-\rho^{s} \omega^{2} u_{i}^{s(0)} & =\frac{\partial \sigma_{i j}^{s(0)}}{\partial x_{j}}+\frac{\partial \sigma_{i j}^{s(1)}}{\partial y_{j}} \\
\rho_{0}^{f} j \omega v_{i}^{f(0)} & =\frac{\partial \sigma_{i j}^{f(0)}}{\partial x_{j}}+\frac{\partial \sigma_{i j}^{f(1)}}{\partial y_{j}} \\
-\frac{\partial q_{i}^{f(1)}}{\partial y_{i}} & =j \omega \rho_{0}^{f} C_{p}^{f} \tau^{f(0)}-j \omega p^{f(0)}
\end{aligned}
$$

$$
\begin{gathered}
\sigma_{i j}^{s(0)}=\frac{1}{2} c_{i j k l}^{s}\left(\frac{\partial u_{k}^{s(0)}}{\partial x_{l}}+\frac{\partial u_{l}^{s(0)}}{\partial x_{k}}\right) \\
+\frac{1}{2} c_{i j k l}^{s}\left(\frac{\partial u_{k}^{s(1)}}{\partial y_{l}}+\frac{\partial u_{l}^{s(1)}}{\partial y_{k}}\right) \\
\sigma_{i j}^{f(0)}=-p^{f(0)} \delta_{i j} \\
\rho_{0}^{f}\left[\frac{\partial v_{i}^{f(0)}}{\partial x_{i}}+\frac{\partial v_{i}^{f(1)}}{\partial y_{i}}\right]+j \omega \delta^{(0)}=0 \\
\frac{p^{f(0)}}{P_{0}}=\frac{\delta^{(0)}}{\rho_{0}^{f}}+\frac{\tau^{f(0)}}{T_{0}}
\end{gathered}
$$

さらに, 式 (23)の $\varepsilon^{1}$ のオーダーから次の関係式が成 り立つ。

$$
\sigma_{i j}^{s(1)} n_{j}^{s}+\sigma_{i j}^{f(1)} n_{j}^{f}=0
$$

\section{3 固体相の支配方程式}

4.3.1 平衡式 まず, $\varepsilon^{-2}$ のオーダーの固体相の 平衡式 (29) より $u^{s(0)}$ が $x$ のみの関数であることが分 かる. また, $\varepsilon^{-1}$ のオーダーの流体相の平衡式 (30) と $\varepsilon^{0}$ のオーダーの流体相の構成式 (35)より $p^{f(0)}$ がxの みの関数であることが分かる.

$\varepsilon^{0}$ のオーダーの固体相および流体相の平衡式 (31), (32) から， $\sigma_{i j}^{s(1)} と \sigma_{i j}^{f(1)}$ が周期解を持つための条件と して, 構成式 (35) および $\varepsilon^{1}$ のオーダーにおける境界 $\Gamma^{s f}$ での応力のつりあい条件式 (38) を考慮すると，次 の式を得ることができる.

$$
\begin{aligned}
-\rho^{s} \omega^{2} u_{i}^{s(0)}(\boldsymbol{x}) & +\rho_{0}^{f} j \omega\left\langle v_{i}^{f(0)}\right\rangle \\
& =\frac{\partial\left\langle\sigma_{i j}^{s(0)}\right\rangle}{\partial x_{j}}+\frac{\partial\left(-\phi p^{f(0)}(\boldsymbol{x})\right)}{\partial x_{i}}
\end{aligned}
$$

なお〈〉は $Y$ における体積平均を表す。ここで， $\varepsilon^{0}$ のオーダーにおける流体相の固体相に対する相対速度 $w_{i}^{f(0)}=v_{i}^{f(0)}-j \omega u_{i}^{s(0)}$ を導入し，その体積平均を上式 に代入すると，以下のマクロスケールにおける平衡式 
を得ることができる.

$$
\begin{aligned}
-\bar{\rho} \omega^{2} u_{i}^{s(0)}(\boldsymbol{x})+ & \rho_{0}^{f} j \omega\left\langle w^{f(0)}\right\rangle \\
& =\frac{\partial\left\langle\sigma_{i j}^{s(0)}\right\rangle}{\partial x_{j}}+\frac{\partial\left(-\boldsymbol{\phi} p^{f(0)}(\boldsymbol{x})\right)}{\partial x_{i}}
\end{aligned}
$$

なお, $\bar{\rho}$ は多孔質体の平均質量密度で $(1-\phi) \rho^{s}+\phi \rho_{0}^{f}$ である.

4.3.2 構成式 $\varepsilon^{1}$ のオーダーにおける固体相の 変位 $u_{i}^{s(1)}$ は，線形性を考慮すると $\chi_{i}^{p q}(\boldsymbol{y}), \eta_{i}(\boldsymbol{y})$ を $Y$-periodic な特性関数として以下のように書くことが できる.

$$
u_{i}^{s(1)}=-\chi_{i}^{p q}(\boldsymbol{y}) \varepsilon_{p q}^{s(0)}(\boldsymbol{x})-\eta_{i}(\boldsymbol{y}) p^{f(0)}(\boldsymbol{x})
$$

ここで, $\varepsilon_{k l}^{s(0)}(\boldsymbol{x})=\frac{1}{2}\left(\frac{\partial u_{k}^{s(0)}(\boldsymbol{x})}{\partial x_{I}}+\frac{\partial u_{l}^{s(0)}(\boldsymbol{x})}{\partial x_{k}}\right)$ である. これを $\varepsilon^{0}$ のオーダーの固体相の構成式 (34) に代入し 体積平均をとると，次式で表わされるようにマクロス ケールにおける固体相の構成式を得ることができる.

$$
\left\langle\sigma_{i j}^{s(0)}\right\rangle=c_{i j k l}^{H} \varepsilon_{k l}^{s(0)}(\boldsymbol{x})-k_{i j}^{H} p^{f(0)}(\boldsymbol{x})
$$

ここで, $c_{i j k l}^{H}, k_{i j}^{H}$ はそれぞれ均質化弾性俰数, 均質化 連成係数で，それぞれ以下の式で求めることができる，

$$
\begin{aligned}
c_{i j k l}^{H} & =\frac{1}{|Y|} \int_{Y}\left[c_{i j k l}^{s}-c_{i j p q}^{s} \frac{\partial \chi_{p}^{k l}(\boldsymbol{y})}{\partial y_{q}}\right] d Y \\
k_{i j}^{H} & =\frac{1}{|Y|} \int_{Y} c_{i j k l}^{s} \frac{\partial \eta_{k}(\boldsymbol{y})}{\partial y_{l}} d Y
\end{aligned}
$$

ただし， $|Y|$ はユニットセル $Y$ の体積である.

\section{4 流体相の支配方程式}

4.4.1 平衡式 $\varepsilon^{0}$ のオーダーの流体相の速度場 の平衡式 (32) に相対速度 $w_{i}^{f(0)}=v_{i}^{f(0)}-j \omega u_{i}^{s(0)}(\boldsymbol{x})$ を 代入すると以下のように書ける。

$$
\rho_{0}^{f} j \omega w_{i}^{f(0)}-\frac{\partial \sigma_{i j}^{f(1)}}{\partial y_{j}}=\rho_{0}^{f} \omega^{2} u_{i}^{s(0)}(\boldsymbol{x})-\frac{\partial p^{f(0)}(\boldsymbol{x})}{\partial x_{i}}
$$

右辺の $\boldsymbol{y} に は$ 依存しない項に対する線形性を考慮する と, $Y$-periodic な特性関数 $\xi_{i}^{k}(\boldsymbol{y})$ を用いて, $w_{i}^{f(0)}$ は次 式のように書くことができる.

$$
w_{i}^{f(0)}=\xi_{i}^{k}(\boldsymbol{y})\left[\rho_{0}^{f} \omega^{2} u_{k}^{s(0)}(\boldsymbol{x})-\frac{\partial p^{f(0)}(\boldsymbol{x})}{\partial x_{k}}\right]
$$

この式の領域 $Y$ における体積平均をとると, $u^{s(0)}$ と $p^{f(0)}$ はxのみの関数であるから次のように書ける.

$$
\left\langle w_{i}^{f(0)}\right\rangle=\left\langle\xi_{i}^{k}(\boldsymbol{y})\right\rangle\left[\rho_{0}^{f} \omega^{2} u_{k}^{s(0)}(\boldsymbol{x})-\frac{\partial p^{f(0)}(\boldsymbol{x})}{\partial x_{k}}\right]
$$

これは応力勾配と速度の関係を表したものであり，平 衡式として解釈できる。

4.4.2 構成式 $\varepsilon^{0}$ のオーダーの流体相の質量保 存則 (36) に関して $Y$ における体積平均をとると次の 式を得ることができる。

$$
\frac{\partial\left\langle v_{i}^{f(0)}\right\rangle}{\partial x_{i}}+\frac{1}{|Y|} \int_{Y} \frac{\partial v_{i}^{f(1)}}{\partial y_{i}} d Y=-j \omega \frac{\left\langle\delta^{(0)}\right\rangle}{\rho_{0}^{f}}
$$

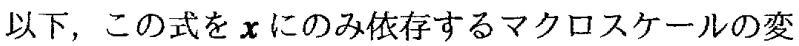
数と係数を用いて表すことを考える.

まず, 左辺の第一項に相対速度の体積平均 $\left\langle w_{i}^{f(0)}\right\rangle=$ $\left\langle v_{i}^{f(0)}\right\rangle-j \omega \phi u_{i}^{s(0)}(\boldsymbol{x})$ を代入すると以下のように書き 直せる.

$$
\begin{array}{r}
\frac{\partial\left\langle w_{i}^{f(0)}\right\rangle}{\partial x_{i}}+j \omega \phi \frac{\partial u_{i}^{s(0)}(\boldsymbol{x})}{\partial x_{i}}+\frac{1}{|Y|} \int_{Y} \frac{\partial v_{i}^{f(1)}}{\partial y_{i}} d Y \\
=-j \omega \frac{\left\langle\delta^{(0)}\right\rangle}{\rho_{0}^{f}}
\end{array}
$$

次に，上式右辺の密度項について考える. $\varepsilon^{0}$ の オーダーにおける流体相の温度 $\tau^{f(0)}$ は, 式 (33) か ら $p^{f(0)}(\boldsymbol{x})$ に対して線形性があることが分かる，この ことを考慮すると， $\tau^{f(0)}$ は $\zeta(\boldsymbol{y})$ を $Y$-periodic な特性 関数として以下のように表すことができる.

$$
\tau^{f(0)}=\frac{1}{\rho_{0}^{f} C_{p}^{f}} \zeta(\boldsymbol{y}) p^{f(0)}(\boldsymbol{x})
$$

この式の領域 $Y$ における体積平均をとり， $\varepsilon^{0}$ のオー ダーにおける状態方程式 (37) の体積平均に代入して $\tau^{f(0)}$ を消去すると以下に示すように密度の体積平均 $\left\langle\delta^{(0)}\right\rangle$ を圧力 $p^{f(0)}(\boldsymbol{x})$ を用いて表すことができる。

$$
\begin{aligned}
-j \omega \frac{\left\langle\delta^{(0)}\right\rangle}{\rho_{0}^{f}} & =-j \omega \frac{\phi}{K^{f}} p^{f(0)}(\boldsymbol{x}) \\
K^{f} & =\frac{\gamma P_{0}}{\gamma-(\gamma-1) \frac{1}{\phi}\langle\zeta(\boldsymbol{y})\rangle}
\end{aligned}
$$

ここで, $K^{f}$ は流体相の等価的な体積弾性率である. これを式 (49) に代入すると次式のように変形できる.

$$
\begin{aligned}
\frac{\partial\left\langle w_{i}^{f(0)}\right\rangle}{\partial x_{i}}+j \omega \phi \frac{\partial u_{i}^{s(0)}(\boldsymbol{x})}{\partial x_{i}} & +\frac{1}{|Y|} \int_{Y} \frac{\partial v_{i}^{f(1)}}{\partial y_{i}} d Y \\
& =-j \omega \frac{\phi}{K^{f}} p^{f(0)}(\boldsymbol{x})
\end{aligned}
$$

最後に, 上式の左辺第三項について考える. $\varepsilon^{1}$ の オーダーにおける $\Gamma^{s f}$ での境界条件式 (38) の弱形式 に Gauss の発散定理を用いると，次式が成り立つ.

$$
\frac{1}{|Y|} \int_{Y} j \omega \frac{\partial u_{i}^{s(1)}}{\partial y_{i}} d Y+\frac{1}{|Y|} \int_{Y} \frac{\partial v_{i}^{f(1)}}{\partial y_{i}} d Y=0
$$

これを式(53)に代入すると，以下のように書き直すこ 
とができる。

$$
\begin{aligned}
\frac{\partial\left\langle w_{i}^{f(0)}\right\rangle}{\partial x_{i}}+j \omega \phi \frac{\partial u_{i}^{s(0)}(\boldsymbol{x})}{\partial x_{i}} & -\frac{1}{|Y|} \int_{Y} j \omega \frac{\partial u_{i}^{s(1)}}{\partial y_{i}} d Y \\
& =-j \omega \frac{\phi}{K^{f}} p^{f(0)}(\boldsymbol{x})
\end{aligned}
$$

そして, 式(41)を代入し $u_{i}^{s(1)}$ を消去すると, 次式に 示すマクロスケールにおける流体相の構成式を導出す ることができる。

$$
\begin{aligned}
\frac{\partial\left\langle w_{i}^{f(0)}\right\rangle}{\partial x_{i}}+j \omega \phi & \frac{\partial u_{i}^{s(0)}(\boldsymbol{x})}{\partial x_{i}}+j \omega \theta^{s, p q} \varepsilon_{p q}^{s(0)} \\
& +j \omega\left(\theta^{f}+\frac{\phi}{K^{f}}\right) p^{f(0)}(\boldsymbol{x})=0
\end{aligned}
$$

ここで， $\theta^{s, p q}, \theta^{f}$ はそれぞれ以下のように定義して いる。

$$
\begin{aligned}
\theta^{s, p q} & =\frac{1}{|Y|} \int_{Y} \frac{\partial \chi_{k}^{p q}(\boldsymbol{y})}{\partial y_{k}} d Y \\
\theta^{f} & =\frac{1}{|Y|} \int_{Y} \frac{\partial \eta_{k}(\boldsymbol{y})}{\partial y_{k}} d Y
\end{aligned}
$$

上式からも分かるように， $\theta^{s, p q}, \theta^{f}$ はそれぞれ特性 変位 $\chi_{i}^{p q}(\boldsymbol{y})$ および $\eta_{i}(\boldsymbol{y})$ の平均体積ひずみであり, 固 体相と流体相の連成の度合いを表している.

以上に示したように，質量保存則に，ミクロスケー ルにおける温度場の影響と状態方程式を考慮すること で。流体相の圧力と体積ひずみの関係を表すマクロな 構成式 (56) が得られる。

4.5 支配方程式の弱形式 前節までで各相のマ クロスケールにおける平衡式と楧成式，すなわち固体 相については式 (40)と (42), 流体相については式 (47) と(56)が得られており，ここでは，それらを用いて各 相の支配方程式の弱形式を導く. なお，固体相は変位 $u_{i}^{s(0)}(\boldsymbol{x})$ が求めるべき未知の状態量であり，流体相に ついては，離散化したときの解析自由度を小さくする ため, 式(47)を用いて $\left\langle w_{i}^{f(0)}\right\rangle$ を消去し, 圧力 $p^{f(0)}(\boldsymbol{x})$ を末知の状態量とする。

式 (40) は，式 (47) を代入すると以下のように畫き 直すことができる．

$$
\begin{array}{r}
\frac{\partial \hat{\sigma}_{i j}^{s(0)}}{\partial x_{j}}+\bar{\rho} \omega^{2} u_{i}^{s(0)}-\rho_{0}^{f} \omega^{2} d_{i}^{k} u_{k}^{s(0)}-j \omega d_{i}^{k} \frac{\partial \psi^{f(0)}}{\partial x_{k}} \\
+j \omega \phi \frac{\partial \psi^{f(0)}}{\partial x_{i}}+j \omega k_{i j}^{H} \frac{\partial \psi^{f(0)}}{\partial x_{j}}=0
\end{array}
$$

ただし， $\psi^{f(0)}$ は $p^{f(0)}(\boldsymbol{x})=-j \omega \psi^{f(0)}$ と定義されるポ テンシャル関数, $\hat{\sigma}_{i j}^{s(0)}$ は流体相との連成を考慮しな い場合の固体相の忘力で $\hat{\sigma}_{i j}^{s(0)}=c_{i j k l}^{H} \varepsilon_{k l}^{s(0)}$ である。 ま た, $d_{i}^{k}$ は

$$
d_{i}^{k}=\rho_{0}^{f} j \omega\left\langle\xi_{i}^{k}(\boldsymbol{y})\right\rangle
$$

\section{で定義している.}

同様に式 (56) は，式 (47) を代入すると次式のよう に書くことができる。

$$
\begin{aligned}
\frac{d_{i}^{k}}{\rho_{0}^{f}} \frac{\partial^{2} \psi^{f(0)}}{\partial x_{k} \partial x_{i}}+ & \omega^{2}\left(\theta^{f}+\frac{\phi}{K^{f}}\right) \psi^{f(0)}-j \omega d_{i}^{k} \frac{\partial u_{k}^{s(0)}}{\partial x_{i}} \\
& +j \omega \phi \frac{\partial u_{i}^{s(0)}}{\partial x_{i}}+j \omega \theta^{s, p q} \varepsilon_{p q}^{s(0)}=0
\end{aligned}
$$

式 (59) と式 (61) はそれぞれ, Biot のモデルの式 (1) と式 (2) に対応するものとなっていることが分かる。 そして，式 (59)，(61)にGalerkin 法を適用すると固体 相および流体相の支配方程式の弱形式は，それぞれ以 下のように表すことができる。

$$
\begin{gathered}
\int_{\Omega^{p}}\left[\hat{\sigma}_{i j}^{s(0)} \delta \varepsilon_{i j}^{s}-\bar{\rho} \omega^{2} u_{i}^{s(0)} \delta u_{i}^{s}+\rho_{0}^{f} \omega^{2} d_{i}^{k} u_{k}^{s(0)} \delta u_{i}^{s}\right. \\
\left.+j \omega d_{i}^{k} \frac{\partial \psi^{f(0)}}{\partial x_{k}} \delta u_{i}^{s}+j \omega \phi \psi^{f(0)} \delta \varepsilon_{k k}^{s}+j \omega k_{i j}^{H} \psi^{f(0)} \delta \varepsilon_{i j}^{s}\right] d \Omega \\
=\int_{\Gamma^{p}} \sigma_{i j}^{p} n_{j}^{p} \delta u_{i}^{s} d \Gamma \quad(62) \\
\int_{\Omega^{p}}\left[-\frac{d_{i}^{k}}{\rho_{0}^{f}} \frac{\partial \psi^{f(0)}}{\partial x_{k}} \frac{\partial \delta \psi^{f}}{\partial x_{i}}+\omega^{2}\left(\theta^{f}+\frac{\phi}{K^{f}}\right) \psi^{f(0)} \delta \psi^{f}\right. \\
\left.+j \omega d_{i}^{k} u_{k}^{s(0)} \frac{\partial \delta \psi^{f}}{\partial x_{i}}+j \omega \phi \varepsilon_{k k}^{s(0)} \delta \psi^{f}+j \omega \theta^{s, i j} \varepsilon_{i j}^{s(0)} \delta \psi^{f}\right] d \Omega \\
=-\int_{\Gamma^{p}}\left\langle w_{i}^{f(0)}\right\rangle n_{i}^{f} \delta \psi^{f} d \Gamma \quad
\end{gathered}
$$

ただし， $\Omega^{p}$ は多孔質体の占める領域， $\Gamma^{p}$ はその境界， $n_{i}^{p}$ は $\Gamma^{p}$ にたてた単位法線ベクトルである。また， $\sigma_{i j}^{p}$ は固体相と流体相の合応力で $\sigma_{i j}^{p}=\left\langle\sigma_{i j}^{s(0)}\right\rangle+\left\langle\sigma_{i j}^{f(0)}\right\rangle$ で ある。

なお, 式 (62)，(63)では, 質量密度からなる係数の 他に，ミクロスケールのユニットセル $Y$ における体積 平均から求められる $c_{i j k l}^{H}, k_{i j}^{H}, \theta^{s, p q}, \theta^{f}, K^{f}, d_{i}^{k}$ が含 まれる。これらの算出に必要な $Y$-periodic な特性関数 $\chi_{i}^{p q}(\boldsymbol{y}), \eta_{i}(\boldsymbol{y}), \quad \xi_{i}^{k}(\boldsymbol{y}), \zeta(\boldsymbol{y})$ を計算する方法は著者ら の文献 ${ }^{(11)}$ を参照されたい.

$4.6 K^{f} / K^{s} \rightarrow 0$ の場合の支配方程式 流体相の 体積弾性率 $K^{f}$ に比して固体相の体積弾性率 $K^{s}$ が十 分大きく, 固体相の変位 $u_{i}^{s}$ を 0 とみなせる場合には, 流体相の挙動のみを考えればよい.このとき流体相の 平衡式と構成式はそれぞれ，式 (47) と (56) より以下 の式で表される。

$$
\begin{aligned}
\left\langle w_{i}^{f(0)}\right\rangle & =-\left\langle\xi_{i}^{k}(\boldsymbol{y})\right\rangle \frac{\partial p^{f(0)}(\boldsymbol{x})}{\partial x_{k}} \\
\frac{1}{j \omega} \frac{\partial\left\langle w_{i}^{f(0)}\right\rangle}{\partial x_{i}} & =-\frac{\phi}{K^{f}} p^{f(0)}(\boldsymbol{x})
\end{aligned}
$$


平衡式を構成式に代入し， $p^{f(0)}=-j \omega \psi^{f(0)}$ で定義さ れるポテンシャル $\psi^{f(0)}$ を用いると, 次の Helmholtz の方程式を得ることができる.

$$
\frac{d_{i}^{k}}{\rho_{0}^{f}} \frac{\partial^{2} \psi^{f(0)}}{\partial x_{k} \partial x_{i}}+\frac{\phi}{K^{f}} \omega^{2} \psi^{f(0)}=0
$$

すなわち，多孔質体の挙動は等価的な質量密度および 体積弾性率を有する流体として表現できることが分 かる.

$4.7 \varepsilon \rightarrow 0$ の場合の支配方程式ユニニッセル が波長に比して非常に小さい $\varepsilon \rightarrow 0$ の場合, すなわち 流体相の流路断面が非常に小さい場合, 流体の粘性の ため流体相の固体相に対する相対速度 $\left\langle w^{f}(0)\right\rangle$ は 0 と なり, 式 (40)より固体相の平衡式は次式となる.

$$
-\bar{\rho} \omega^{2} u_{i}^{s(0)}(\boldsymbol{x})=\frac{\partial\left\langle\sigma_{i j}^{s(0)}\right\rangle}{\partial x_{j}}+\frac{\partial\left(-\phi p^{f(0)}\right)}{\partial x_{i}}
$$

また，固体相および流体相の構成式は，式 (42)，(56) より，それぞれ以下のように書くことができる.

$$
\begin{gathered}
\left\langle\boldsymbol{\sigma}_{i j}^{s(0)}\right\rangle=c_{i j k l}^{H} \varepsilon_{k l}^{s(0)}(\boldsymbol{x})-k_{i j}^{H} p^{f(0)}(\boldsymbol{x}) \\
-\left(\boldsymbol{\theta}^{f}+\frac{\phi}{K^{f}}\right) p^{f(0)}(\boldsymbol{x})=\phi \varepsilon_{k k}^{s(0)}+\boldsymbol{\theta}^{s, p q} \varepsilon_{p q}^{s(0)}
\end{gathered}
$$

以上より支配方程式は，固体相と流体相の合応力 $\sigma_{i j}^{p}$ を用いると以下の式で表される。

$$
\begin{gathered}
-\bar{\rho} \omega^{2} u_{i}^{s(0)}(\boldsymbol{x})=\frac{\partial \sigma_{i j}^{p}}{\partial x_{j}} \\
\sigma_{i j}^{p}=c_{i j k l}^{H} \varepsilon_{k l}^{s(0)}+\alpha_{i j}\left(\phi \varepsilon_{k k}^{s(0)}+\theta^{s, p q} \varepsilon_{p q}^{s(0)}\right) \\
\alpha_{i j}=\frac{k_{i j}^{H}+\phi \delta_{i j}}{\theta^{f}+\phi / K^{f}}
\end{gathered}
$$

すなわち，この場合，多孔質体の挙動は弾性体として 表現できることが分かる.

\section{5. 数 值 例}

式 (62)，(63)に示すマルチスケール解析により導出 した多孔質体モデルを用いて，多孔質吸音材の代表的 なマクロ特性である垂直入射吸音率を計算し，解析解 と比較することにより数值解の精度を検証する．また， 本モデルを簡単なミクロ構造を有する多孔質吸音材に 適用し，ミク口構造の特性や実際の大きさの違いが, マクロ特性にどのように影響するかを調べる．

$5 \cdot 1$ 解析解との比較 ここでは解析解を求める ことができる，二次元的で均一な流路断面を有する多 孔質吸音材を用いる．なお，材料の厚さは $0.020 \mathrm{~m}$ と する. 垂直入射吸音率の解析解は, 式 (1), (2) に示し た Biot のモデルを用いて求めることができる，詳細

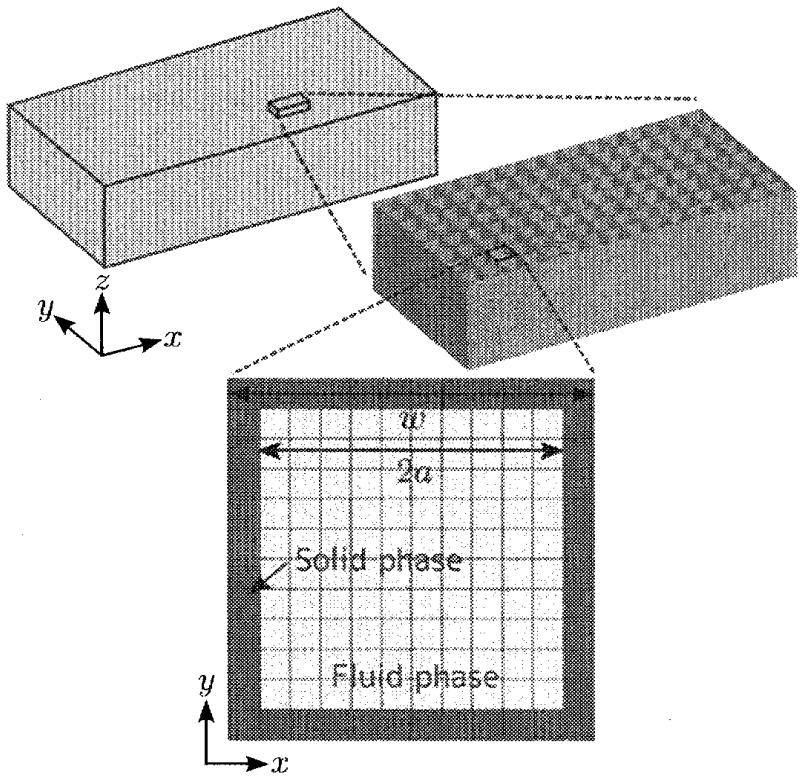

Fig. 1 Poroelastic material with fluid phase in rectangular section.

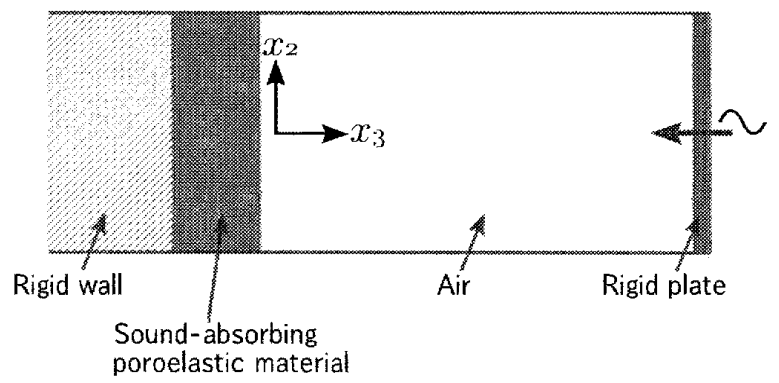

Fig. 2 Model of acoustic tube for calculating sound absorption coefficient for normal incidence.

には Allard ${ }^{(4)} や$ Stinson ${ }^{(14)}$ を参照されたい。

図 1 に示すように，一辺が $w$ の正方形状のユニット セル中に, 縦横ともに $2 a$ の大きさの矩形状の流路を 有する多孔質体を考える。ここでは，解析解と比較す るため, 各相の運動は $z$ 軸方向のみを考えるものとす る.したがって, $x$ および $y$ 軸方向には流路が連結し ていないが問題はない. ユニットセルおよび流路の大 きさはそれぞれ, $w=120 \mu \mathrm{m}, 2 a=100 \mu \mathrm{m}$ とし，数 值解はユニットセル各辺を四辺形要素で $12,24,48$, 96 分割する 4 パターンについて求める。 なお, 図 1 には分割数が 12 の場合のユニットセルモデルを示し ている. 固体相を構成する材料のヤング率は $1.0 \times 10^{7}$ $\mathrm{Pa}$, 損失係数は 0.100 , 流体相は空気の特性を有する ものとする，計算の手順としては，最初にユニットセ ルによるミクロスケールの計算を行い均質化特性を求 める. すなわち, 特性関数 $\chi_{i}^{p q}(\boldsymbol{y}), \eta_{i}(\boldsymbol{y}), \xi_{i}^{k}(\boldsymbol{y}), \zeta(\boldsymbol{y})$ を求め, 式 (43), (44), (57), (58) を用いて $c_{i j k l}^{H}, k_{i j}^{H}$, 
$\theta^{s, p q}, \theta^{f}$ ，式 (52)，(60)を用いて $K^{f} ， d_{i}^{k}$ を算出する. そしてこれらの值と式 (62)，(63) および図 2 に示すよ うな音響管モデルを用いてマクロスケールの計算を行 うことで，垂值入射吸音率を求めることができる。

図 3 には垂直入射吸音率の数值解と解析解の相対䛊 差を示している．要素分割が粗い場合でも， $1.5 \%$ 以 内の誤差であり，良い精度の解が得られていることが 分かる。また, 数值解は要素分割数が増加するにつれ 解析解へ収束することが確認できる。

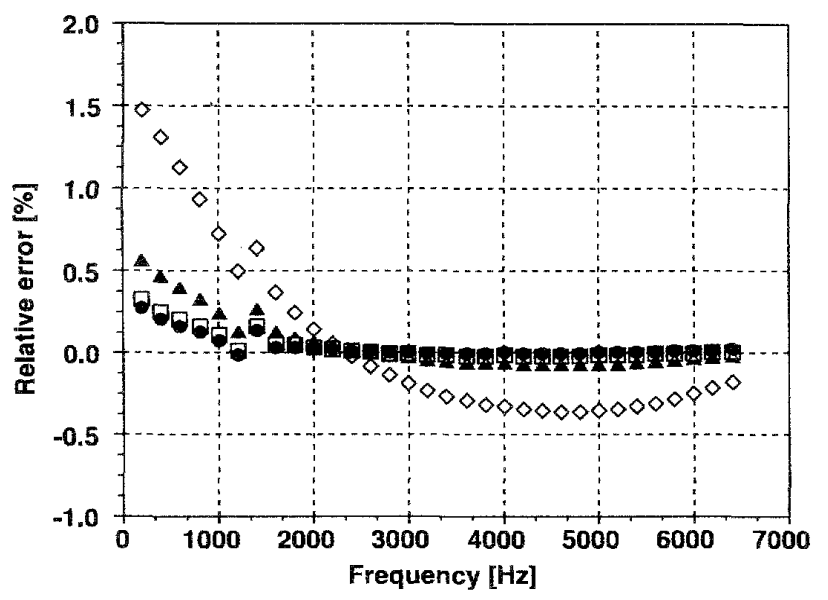

Fig. 3 Relative error of sound absorption coefficient for poroelastic material with fluid phase in rectangular section. Number of elements per unit cell side is $12(\diamond), 24(\mathbf{\Delta}), 48(\square), 96(\bullet)$.

5.2 三次元モデルへの応用例 三次元的なミク 口構造を有する多孔質吸音材について，ミクロ構造の 特性や実際の大きさが，マク口特性である垂直入射吸 音率に及ぼす影響を数值的に調べる。ここでは，一辺 が $w$ の立方体のユニットセル中に，2a=5/6wの大き さの矩形状の流路が直交している多孔質体を考え，図 4 に示すように $24^{3}$ 個の六面体要素でモデル化する.

まず，固体相を構成する材料のヤング率 $E^{s}$ を変え たとき，垂直入射吸音率がどのように変化するかを見 る.図 5 には $1.0 \times 10^{6} \mathrm{~Pa}, 1.0 \times 10^{8} \mathrm{~Pa}, 4.0 \times 10^{8} \mathrm{~Pa}$, $6.0 \times 10^{8} \mathrm{~Pa}$ と変化させたときの垂直入射吸音率を示 している.また, $E^{s}$ が限りなく大きい場合として，多 孔質吸音材を等価的な流体，すなわち式 (66) で表した 場合の垂直入射吸音率も示している，なお，固体相を 構成する材料の損失係数は 0.100 , 密度は $1000 \mathrm{~kg} / \mathrm{m}^{3}$, 流体相の特性は空気の特性とする. $E^{s}$ が小さい場合は, 固体相の共振による吸音効果が大きく, $E^{s}=6.0 \times 10^{8}$ $\mathrm{Pa}$ の場合は固体相の共振は $5 \mathrm{kHz}$ 以上で, それ以下 の周波数では流体相の挙動で性能が決まっていること が分かる。

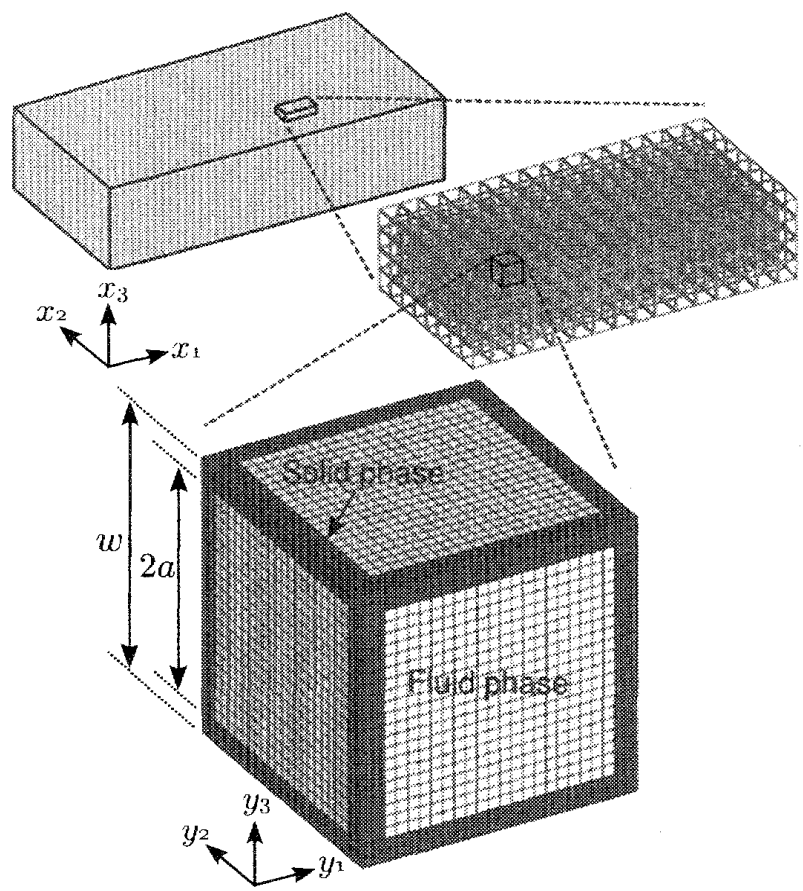

Fig. 4 Poroelastic material with fluid phase in rectangular section in three-dimensional unit cell.

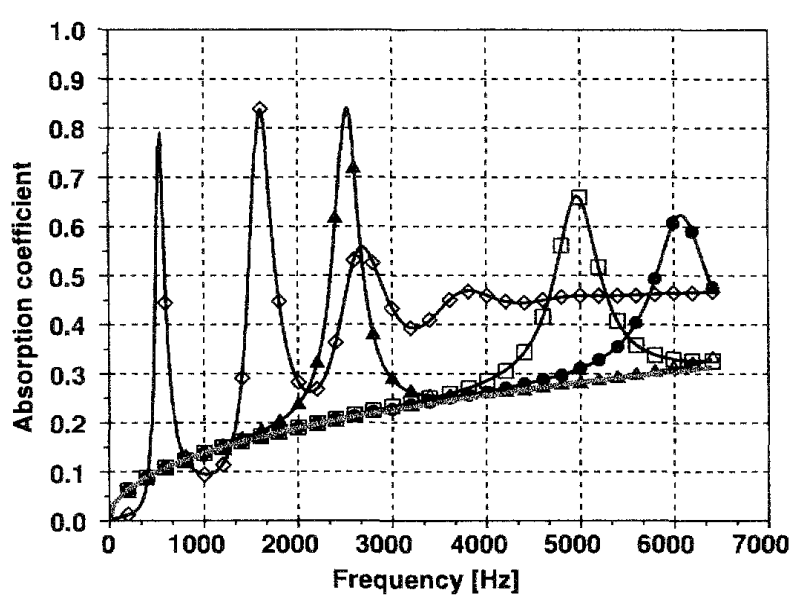

Fig. 5 Sound absorption coefficient for normal incidence for a variety of material stiffness; Young's modulus of material $E^{s}$ is $1.0 \times 10^{6}$ $\mathrm{Pa}(\diamond), \quad 1.0 \times 10^{8} \mathrm{~Pa}(\mathbf{\Delta}), 4.0 \times 10^{8} \mathrm{~Pa}(\square)$, $6.0 \times 10^{8} \mathrm{~Pa}(\bullet)$. Gray line corresponds to the case when $E^{s}$ is infinitely large.

次に，流体相の流路断面の大きさを変えたとき，垂 直入射吸音率がどのように変化するかを見る．ただし， 空孔率を一定に保つものとする。この場合，流路断面 の大きさの変化は, ユニットセル一辺の大きさ $w$ を 変えることで表現できる。図 6 には $w$ が $12 \mu \mathrm{m}, 30$ 


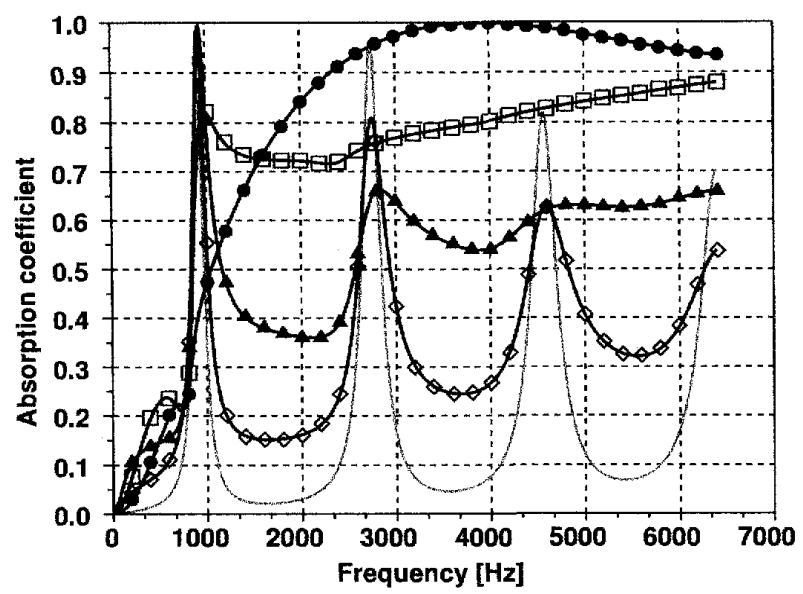

Fig. 6 Sound absorption coefficient for normal incidence for different unit cell size; $w$ is $12 \mu \mathrm{m}$ $(\diamond), 30 \mu \mathrm{m}(\Delta), 60 \mu \mathrm{m}(\square), 120 \mu \mathrm{m}(\bullet)$. Gray line corresponds to the case $w$ is infinitely small.

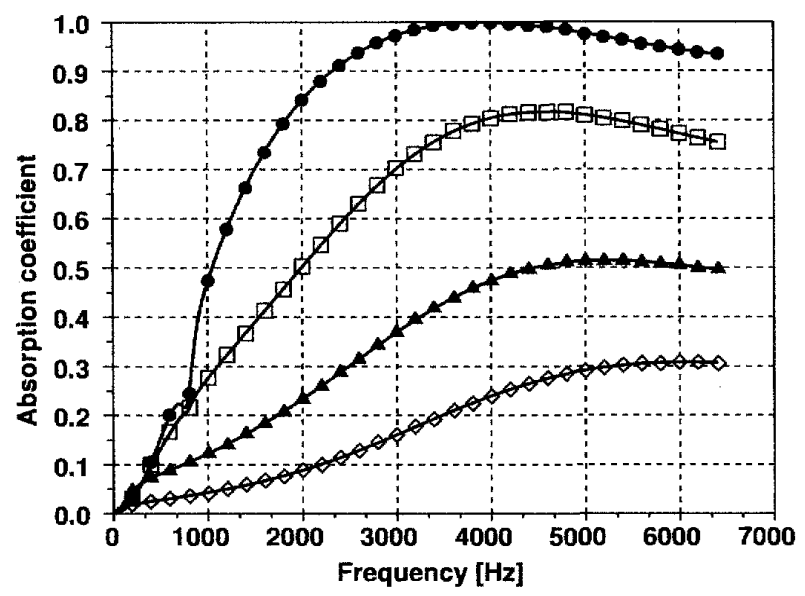

Fig. 7 Sound absorption coefficient for normal incidence for different unit cell size; $w$ is $1200 \mu \mathrm{m}$ $(\diamond), 480 \mu \mathrm{m}(\Lambda), 240 \mu \mathrm{m}(\square), 120 \mu \mathrm{m}(\bullet)$.

$\mu \mathrm{m}, 60 \mu \mathrm{m}, 120 \mu \mathrm{m}$, 図 7 には $w$ が $120 \mu \mathrm{m}, 240$ $\mu \mathrm{m}, 480 \mu \mathrm{m}, 1200 \mu \mathrm{m}$ の場合の垂直入射吸音率を示 す.また，図 6 には，流路断面の大きさが限りなく小 さい場合として，多孔質吸音材を等価的な弾性体，す なわち式 (70)〜(72) で表した場合の垂直入射吸音率も 示している. なお，固体相を構成する材料のヤング率 は $1.0 \times 10^{7} \mathrm{~Pa}$ ，損失係数は 0.100 ，密度は $1000 \mathrm{~kg} / \mathrm{m}^{3}$ ， 流体相の特性は空気の特性とする. $w=120 \mu \mathrm{m}$ の場 合, すなわち $2 a=100 \mu \mathrm{m}$ の場合に $2 \mathrm{kHz}$ から $6 \mathrm{kHz}$ の間で最も高い吸音率を示しており，流路断面の大き さが大きくなるにつれて吸音効果は小さくなる。これ は，吸音材の空孔サイズが大きすぎると吸音材として
のはたらきがなくなることを示している，逆に流路断 面の大きさが小さくなるにつれて固体相の共振による 吸音が主となり， $w=12 \mu \mathrm{m}$ の場合は等価的な弾性体 としての挙動に近づいている.

以上，図 5〜7で示した吸音率の変化は物理的な見地 からも妥当な結果である. また, 図 6,7の結果から, ミクロ構造の寸法効果も考慮できることが分かる．こ れは, 式 (22) に示すように固体相と流体相の境界 $\Gamma^{s f}$ に固着条件を設定しているためであると考えられる.

このように, 本提案手法により, ミクロ構造からマ クロ特性である吸音率を予測したり，多孔質吸音材の 具体的なミクロ構造を設計することが可能になると考 えられる。

\section{6. 結言}

本論文では, 多孔質吸音材に対して現在適用されて

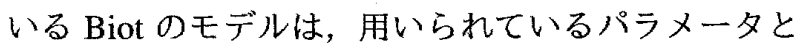
ミクロ構造の関保性を欠いていることに対し，漸近展 開法に基づく均質化法を用いて，ミクロ構造と整合の とれた多孔質吸音材の新しいモデルを提案した。得ら れた結果を以下にまとめる.

（1）多孔質吸音材を対象に漸近展開法に基づく均 質化法を用いて，ミクロスケールにおける支配方程式 からマクロスケールにおける支配方程式を導出した。 すなわち，ミクロスケールにおけるユニットセルから

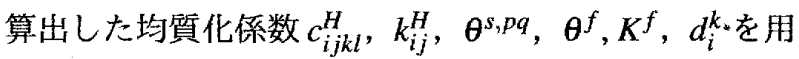
いて，マクロスケールにおける多孔質吸音材の支配方 程式 (62) および (63) を導出した.

（2）導出したマクロスケールにおける支配方程式 は, 固体相の岡性が大きく, 固体相の変位が 0 とでき る場合は流体の支配方程式に等価となり, また多孔質 吸音材の空孔の大きさが無限に小さい場合は弾性体の 支配方程式に等価となることを示した。

（3）解析解を得ることのできる二次元的な流路断 面を有する多孔質吸音材を用いて提案手法による数值 解と解析解を比較検証した結果, 良い精度で数值解を 求めることができること，および数値解が理論解に収 束することを確認した。

(4) 三次元の簡単なミク口構造を有する多孔質吸音 材を用いて，ミクロ構造の特性や実際の大きさの違い がマクロな特性である垂直入射吸音率に与える影響に ついて調べた結果, 物理的にも妥当な結果が得られ, 本提案手法の有効性を実証することができた。 


\section{文献}

(1) Delany, M. E. and Bazley, E. N., Acoustical properties of fibrous absorbent materials, Applied Acoustics, Vol. 3 (1970), pp. $105-116$.

(2) Biot, M. A., Theory of propagation of elastic waves in a fluid-saturated porous solid. I.Low-frequency range, Journal of Acoustical Society of America, Vol. 28 (1956), pp. $168-178$.

(3) Biot, M. A., Theory of propagation of elastic waves in a fluid-saturated porous solid. II. Higher frequency range, Journal of Acoustical Society of America, Vol. 28 (1956), pp. 179 - 191.

(4) Allard, J. F., Propagation of Sound in Porous Media, (1993), Elsevier Applied Science.

(5) Atalla, N., Panneton, R. and Debergue, P., A mixed displacement-pressure formulation for poroelastic materials, Joumal of Acoustical Society of America, Vol. 104 (1998), pp. 1444 - 1452.

(6) Auriault, J. L., Borne, L. and Chambon, R., Dynamics of porous saturated media, checking of the generalized law of darcy, Journal of Acoustical Society of America, Vol. 77 (1985), pp. 1641 - 1650.

(7) Terada, K., Ito, T. and Kikuchi, N., Characterization of the mechanical behaviours of solid-fluid mixture by the homogenization method, Computer Methods in Applied Mechanics and Engineering, Vol. 153 (1998), pp. 223 - 257.

(8) Levy, T., Propagation of waves in a fluid-saturated porous elastic solid, International Journal of
Engineering Science, Vol. 17 (1979), pp. 1005 1014.

(9) Burridge, R. and Keller, J. B., Poroelasticity equations derived fron microstructure, Journal of Acoustical Society of America, Vol. 70 (1981), pp. $1140-1146$

(10) Boutin, C., Royer, P. and Auriault, J. L., Acoustic absorption of porous surfacing with dual porosity, International Journal of Solids and Structures, Vol. 35 (1998), pp. 4709 - 4737.

(11) Yamamoto, T., Maruyama, S., Izui, K., Nishiwaki, S. and Terada, K., Equivalent properties of sound absorbing poroelastic material using the homogenization method, Transactions of the Japan Society of Mechanical Engineers, Series C, Submitted.

(12) Terada, K. and Kikuchi, N., Introduction to the method of homogenization (in Japanese), (2003), Maruzen.

(13) Castagnéde, B., Moussatov, A., Lafarge, D. and Saeid, M., Low frequency in situ metrology of $a b-$ sorption and dispersion of sound absorbing porous materials based on high power ultrasonic nonlinearly demodulated waves, Applied Acoustics, Vol. 69 (2008), pp. $634-648$.

(14) Stinson, M. R., The propagation of plane sound wave in narrow and wide circular tubes, and generalization to uniform tubes of arbitrary crosssectional shape, Journal of Acoustical Society of America, Vol. 89 (1991), pp. 550 - 558. 